\title{
LA PASIÓN TROBADA POR DIEGO DE SAN PEDRO EN LA IMPRENTA MEDIEVAL Y RENACENTISTA: DIFUSIÓN DEL POEMA EN CANCIONEROS Y PLIEGOS SUELTOS*
}

\author{
M. ${ }^{a}$ Carmen Marín Pina \\ Universidad de Zaragoza-IPH \\ mmarin@unizar.es
}

Compuesta en las últimas décadas del siglo xv (1470-1480), la Pasión trobada $(P T)$ por Diego de San Pedro es, sin duda, una de las obras poéticas religiosas de mayor popularidad en el Renacimiento gracias a la imprenta ${ }^{1}$. Escrito en coplas reales o quintillas dobles, este extenso poema devocional es, a juicio de K. Whinnom, la Pasión en verso «más sencilla, la mejor escrita, las más fácil de leer y la más conmovedora $»^{2}$. Su elogiada sencillez radica en un texto deudor de los Evangelios, libre de complejas consideraciones teológicas, y en el que «les faits sont rapportés simplemente, coupés d'exclamations, d'interpellations, d'invitation aux larmes»»3. La monotonía

* Este trabajo se ha realizado en el marco del Proyecto de Investigación FFI2016-75396-P, concedido por el Ministerio de Economía y Competitividad. Se inscribe en el grupo investigador Clarisel, que cuenta con la participación económica del Departamento de Ciencia, Tecnología y Universidad del Gobierno de Aragón y del Fondo Social Europeo.

${ }^{1}$ La datación del poema es imprecisa. En uno de sus primeros trabajos, Keith Whinnom, «The Religious Poems of Diego de San Pedro: their Relationship and their Dating», en Hispanic Review, 38 (1960), pp. 1-15 (p. 13), propone datarla antes de 1480, y posteriormente, en su edición del poema en colaboración con Dorothy S. Severin, Obras completas, III. Poesía, Madrid, Castalia, 1979, p. 11, en la década de los años 70, aduciendo razones estilísticas y de apreciación personal, pero sin pruebas concluyentes. A la vista de las ediciones, Pedro M. Cátedra, Poesía de Pasión en la Edad Media. El «Cancionero» de Pero Gómez de Ferrol, Salamanca, Seminario de Estudios Medievales y Renacentistas, 2001, p. 300, estima, sin embargo, que el primer estado del poema puede fecharse bien entrados los años ochenta. En cualquier caso se considera una de la primeras obras de Diego de San Pedro, anterior a Las Siete Angustias de Nuestra Señora y al Tractado de amores de Arnalte y Lucenda (Burgos, 1491).

${ }^{2}$ Severin y Whinnom, ed. cit., p. 16.

${ }^{3}$ Michel Darbord, La poésie religieuse espagnole des Rois Catholiques à Philippe II, Paris, Centre de Recherches de l'Institut d'Études Hispaniques, 1965, p. 104, aunque la atención que le dedica es muy 
del relato se rompe con las apelaciones del autor al público, pero también con los parlamentos de los personajes a los que cede la palabra (Jesús, el ángel, san Pedro, la Verónica y la Virgen María, entre otros) y le otorgan una vivacidad muy dramática y teatral. Se trata de un ejemplo temprano de las muchas Pasiones compuestas por entonces, muestra de una nueva espiritualidad, la de la devotio moderna, centrada en los Evangelios y en la figura de Cristo (más que en la de María), cuya vida, y en concreto su Pasión, se convierte en tema de lectura, contemplación y meditación ${ }^{4}$.

Del poema de la $P T$ se conservan numerosos testimonios manuscritos e impresos que muestran dos estados diferentes: «uno más breve, representado por ediciones impresas, que se prolonga hasta el Entierro, y otro más extenso, que trata los últimos momentos de la vida de Cristo más ampliamente, así como también los aspectos de la compassio de la Virgen después de la muerte de Cristo» ${ }^{5}$. Las versiones impresas serían el resultado de una revisión y reducción de la obra original. El objetivo del presente estudio es analizar la transmisión de la Pasión trobada en la imprenta, su paso por los cancioneros impresos y, especialmente, su difusión en pliegos sueltos, atendiendo a las transformaciones más significativas experimentadas por la obra en su materialidad y contenido durante su primer siglo de vida ${ }^{6}$.

\section{A ruego de una dama, de una devota monja}

La extensa versión manuscrita (y probablemente la original) es el testimonio más temprano de la $P T$ y se encuentra en el Cancionero de OñateCastañeda (HH1), un cancionero de temática variada, compuesto hacia 1485 y quizá recopilado por Pedro de Escavias. El poema, encabezado por el título

escasa, su estudio es relevante para contextualizar la obra dentro de la poesía religiosa del momento.

${ }^{4}$ Además del indispensable trabajo de Pedro M. Cátedra, ob. cit., pp. 191-298, un preciso repaso por los textos de la Pasión en Castilla y en el contexto europeo brinda Juan Miguel Valero Moreno, «La Pasión según Lucas Fernández», en La corónica, 31:2 (2003), pp. 177-216.

${ }^{5}$ Cátedra, ob. cit., p. 300, que sigue las propuestas de Dorothy Sherman Vivian [Severin], «La Passión trobada, de Diego de San Pedro, y sus relaciones con el drama medieval de la Pasión», en Anuario de Estudios Medievales, 1 (1964), pp. 451-470; «The Earlist Version of Diego de San Pedro La Pasión Trobada», en Romanische Forschungen, 81 (1969), pp. 176-192, y las también expuestas en su edición de la versión extensa manuscrita, La Pasión trobada, Naples, Istituto Universitario Orientale, 1973.

${ }^{6}$ No se abordan los complejos problemas textuales ya señalados por Dorohty S. Severin y Keith Whinnom, ed. cit., p. 95, quienes en el apéndice de su edición (pp. 299-308) reproducen las variantes más significativas de los testimonios entonces conocidos. Todos ellos derivarían de, al menos, tres ediciones perdidas. Al esquema propuesto, habría que sumar ahora el pliego sevillano de 1559. Para un sucinto estado de la cuestión sobre la transmisión de la obra, véase Carmen Parrilla, «La Pasión trovada», en Carlos Alvar y José Manuel Lucía Megías, Diccionario Filológico de Literatura Medieval Española. Textos y transmisión, Madrid, Castalia, 2002, pp. 396-397. Tampoco se consideran las ediciones posteriores al siglo XVI. 
«Pasion trobada por pedro de ssan pedro (sic) a rruego duna dama», consta de más de dos centenares de estrofas, de las cuales las 17 primeras son preliminares ${ }^{7}$. En esta versión manuscrita aparecen 63 coplas que no figuran en el resto de testimonios, 59 de las cuales constituyen un final completamente nuevo del poema, lo que lleva a Dorothy Sherman Severin a concluir que la edición impresa, luego comentada, estaba abreviada y reescrita en su parte final ${ }^{8}$. De creer la rúbrica del poema, Diego de San Pedro lo compone a petición de una innominada dama, iniciando con ello un diálogo con el público femenino sostenido por el poeta a lo largo de toda su producción ${ }^{9}$. En algunas de las versiones impresas, concretamente en todos los pliegos sueltos, la peticionaria del poema se convierte en una devota monja. Aunque el ruego no es inverosímil, no deja de ser curiosa la declaración amorosa con la que el autor responde a la demanda, retratándose como un galán de monjas ${ }^{10}$. En el íncipit en prosa que abre los pliegos se cuenta en tercera persona cómo Diego de San Pedro por «servir» a la religiosa «hovo de trobar la dicha pasión». En palabras de Pedro Cátedra, Diego de San Pedro envía la Pasión trobada a la monja «para que le sirva de instrumento meditativo sobre la Pasión y, en alguna medida, como pago o consuelo de otra pasión más íntimamente humana del autor ${ }^{11}$. Además de componer el poema devocional, el autor obsequia a su peticionaria con unas coplas en las que, al más claro estilo cancioneril y haciendo un juego continuado con la ambivalencia del término «pasión» (religiosa y profana) ${ }^{12}$, le declara su «apasionado» amor y su deseo de olvidarla. Estas doce coplas, sin embargo, solo figuran en dos de los pliegos luego comentados (los impresos en Salamanca y Burgos). En aquellos en los que se suprimen las coplas a la devota monja, los dos íncipit en prosa se funden en uno solo, se elimina la declaración amorosa y, curiosamente, se justifica la

\footnotetext{
${ }^{7}$ Harvard, Houghton Library, ms. fMS Sp. 97; ff. 350r-372r. La cita corresponde a la edición de Dorothy Sherman Severin, El Cancionero de Oñate-Castañeda, con introducción de Michel García, Madison, The Hispanic Seminary of Medieval Studies, 1990, p. 302. Se incluye junto a otros poemas inspirados en la Pasión, como son la Vita Christi de fray Íñigo de Mendoza y las Coplas a la Varonica (sic) de fray Ambrosio Montesino.

${ }^{8}$ Así lo considera Dorothy S. Severin, «The Earliest Version...», art. cit., p. 188.

${ }^{9}$ Recuérdese la dedicatoria del Tractado de amores de Arnalte y Lucenda «a las damas de la Reina» o el Sermón ordenado por Diego de Sant Pedro porque dixeron unas señoras que le desseavan oír; véase Keith Whinnom, Obras completas, I. «Tractado de amores de Arnalte y Lucenda» y «Sermón», Madrid, Castalia, 1973, p. 87 y 174, respectivamente.

${ }^{10}$ Como explica Jesús Gómez, «La tradición literaria del galán de monjas», en Edad de Oro, 9 (1990), pp. 81-92, el amor del devoto de monjas «es un ejercicio muchas veces retórico donde se agudiza el ingenio, al mismo tiempo que se depuran las inclinaciones espirituales, sin que sea necesaria la consumación sexual», p. 90.

${ }^{11}$ Cátedra, ob. cit., p. 344.

${ }^{12}$ Véase, además de los trabajos sobre la poesía cancioneril de Keith Whinnom, Jane Yvonne Tillier, «Passion Poetry in the Cancioneros», en Bulletin of Hispanic Studies, 62:1 (1985), pp. 65-78.
} 
inclusión de las «razones contemplativas» por los intereses de su peticionaria, acordes con la orden religiosa en la que profesa:

A pedimiento y ruego de una devota monja, a la cual era mucho en cargo y gelo podía mandar. En la cual van enxeridas algunas razones contemplativas conformes a la religión y regla de quien ge la mandó trobar. E a fin de provocar a más devoción a los que la oyeren o leyeren (h. ajv) ${ }^{13}$ (Lisboa, c. 1530; Sevilla, 1559).

La referencia a una dama (devota monja) en el origen del poema puede responder al interés femenino por este tipo de composiciones devocionales, de corte franciscano, centradas en la humanidad sufriente de Cristo. Por estas fechas en toda Europa se desarrolla una espiritualidad afectiva de la que participan especialmente las mujeres y que impulsaba a la creyente a desarrollar unos vínculos emocionales muy estrechos con Cristo ${ }^{14}$. No es de extrañar por ello que muchas veces las peticionarias-dedicatarias de este tipo de obras sean mujeres religiosas o laicas. Recuérdese que las Meditationes vitae Christi (c. 1346 y 1364), uno de los textos espirituales clave de las mujeres adscritas al franciscanismo, fueron compuestas por un franciscano toscano para una religiosa clarisa, que fray Íñigo de Mendoza dirigió la Vita Christi (1467-1482) a su madre Juana de Cartagena o que Bernat Fenollar y Pere Martinez dedicaron la Istòria de la Passió (Valencia, 1493) a Isabel de Villena, abadesa del monasterio de la Trinidad de Valencia ${ }^{15}$. Es el tipo de espiritualidad manifestado también por las primeras escritoras religiosas,

\footnotetext{
${ }^{13}$ En los conventos femeninos del otoño de la Edad Media, por ejemplo los de las clarisas, circulaban este tipo de obras cristocéntricas que podían proporcionar algunas briznas teológicas a las monjas del siglo XV, como indica Pedro M. Cátedra, «Lectura femenina en el claustro (España, siglos XIV-XVI)», en Des femmes et des livres: France et Espagne XIV -XVI siècles, ed. de Dominique de Courcelles y Carmen Val Julián, Paris, Publications de l'École Nationale des Chartes, 1999, pp. 7-53, tanto para la lectura comunitaria como para la privada.

${ }^{14}$ Miguel García-Bermejo Giner, «Las destinatarias de la poesía cancioneril castellana pasional del siglo XV», en Literaturwissenschaftliches Jahrbuch, 45 (2004), pp. 57-70 (p. 65).

${ }^{15}$ Aunque como muy bien advierte Marinela Garcia Sempere, «La Pasión trovada de Diego de San Pedro y la Istòria de la Passió de Bernat Fenollar i Pere Martines: algunos paralelos», en El retrato literario: tempestades y naufragios, escritura y reelaboración. Actas del XII Simposio de la Sociedad Española de Literatura General y Comparada, ed. de Miguel Á. Márquez et al., Huelva, Universidad de Huelva, 2000, pp. 509-519, la función de las dedicatarias se revela distinta en cada caso (p. 516). Otros ejemplos brindan también, Pedro M. Cátedra, ob. cit., p. 315, y Juan Miguel Valero Moreno, «Control externo y límite genérico: los pliegos poéticos de la Pasión en el siglo XVI», en La literatura popular impresa en España y en la América colonial: formas y temas, géneros, funciones, difusión, historia y teoría, dir. Pedro Manuel Cátedra García, ed. de María Sánchez Pérez et al., Salamanca, Seminario de Estudios Medievales y Renacentistas, 2006, pp. 253-278 (p. 274). En el siglo XvI, el Comentario del Cantar de los Cantares (1561-1562) de fray Luis de León o La conversión de la Magdalena (1588) de Malón de Chaide se componen a petición de sendas religiosas.
} 
como la dominica Constanza de Castilla en su Devocionario (c. 1465-1478) o la misma Isabel de Villena en su Vita Christi (1497), una obra dedicada a Isabel la Católica. Como otros cultivadores del género devocional, es posible que Diego de San Pedro se hiciera eco de ello y respondiera con la $P T$ a la demanda (real o fingida) de una dama, lo que no obsta para que luego el destinatario último del poema sea un público más amplio (el cristiano lector), cuya devoción y espiritualidad se busca potenciar por la contemplación de la agonía de Cristo. Fuera de estas breves piezas paratextuales en prosa, la figura de la monja desaparece y en el poema el autor apela, a través de los imperativos «contempla», «mira», «piensa», «llora», al lector cristiano y pecador que leyere $\mathrm{u}$ oyere sus versos para empatizar con el dolor de Cristo. A este se refiere también expresamente en el íncipit que precede al poema propiamente dicho, repetido en todos los testimonios impresos, «a fin de provocar a más devotión a los que la leyeren y oyeren» (Salamanca, c. 1496, h. Aiijr).

\section{La Pasión trobada en los Cancioneros impresos}

Los primeros testimonios impresos conservados de la $P T$ aparecen en el cancionero religioso conocido como Cancionero de Zaragoza, salido de los talleres zaragozanos de Pablo Hurus en [1491] (91*VC), 1492 (92VC) y 1495 (95VC). El volumen, impreso en formato in folio, en letra gótica y con el texto dispuesto a doble columna, lo conforman quince piezas. Además de la PT y Las Siete Angustias de Nuestra Señora ${ }^{16}$, se recogen obras de Íñigo de Mendoza, Pero Ximénez, Ervías, Juan Guillardón, Medina, Juan de Mena, Juan de Ciudad Rodrigo, Jorge Manrique y Fernán Pérez de Guzmán. La innominada dama o la devota monja solicitante del poema ha desaparecido por completo, aunque curiosamente se mantiene en los cancioneros $92 \mathrm{VC}$ y 95VC la dedicatoria de la Vita Christi de fray Íñigo de Mendoza a Juana de Cartagena. El renombre de esta noble y culta dama, así como su parentesco con el autor, sin duda alguna otorgaban a la obra mayor autoridad y credibilidad que la que le podía conferir una innominada dama ${ }^{17}$. Su omisión

\footnotetext{
${ }^{16}$ Aunque no tan dilatada en el tiempo, una trayectoria similar a la de la PT presenta su poema Las Siete Angustias de Nuestra Señora, como estudia Dorothy S. Severin, «Diego de San Pedro from Manuscript to Print: the Curious Case of La pasión trobada, Las sietes angustias, and Arnalte y Lucenda», en La corónica, 29:1 (2000), pp. 187-191, y en su libro Del manuscrito a la imprenta en la época de Isabel la Católica, Kassel, Reichenberger, 2004, pp. 5-9. Al margen de su difusión manuscrita, primero lo publicó en el Tractado de amores de Arnalte y Lucenda (Burgos, 1491; pero no en la segunda edición, Burgos, 1522), luego en el Cancionero de Zaragoza (1492) y, posteriormente, como pliego suelto (Medina del Campo, 1534). El planto de la Virgen es una versión ampliada de un fragmento de la $P T$.

${ }^{17}$ Unidas por estrechos lazos de parentesco, Juana de Cartagena, Teresa de Cartagena y Juana de Mendoza parecen formar un círculo de grandes lectoras. De Juana de Cartagena se sabe que no devolvió
} 
lleva consigo obviamente la de las atrevidas coplas amorosas, por otro lado totalmente inapropiadas en un cancionero estrictamente religioso. Antes de que la $P T$ pasara a integrarse en esta recopilación devocional, es posible que circulara, sin embargo, en una versión impresa exenta (¿un temprano pliego suelto?), hoy perdida, en la que Diego de San Pedro habría abreviado la incluida en el Cancionero de Oñate-Castañeda ${ }^{18}$.

Hasta la fecha, el testimonio impreso más antiguo de la Passión trobada data de 1491 y ha sido encontrado e identificado, en fechas recientes, por Mercedes Fernández Valladares como un fragmento perteneciente a un hipotético Cancionero de Zaragoza, salido presumiblemente del taller de los hermanos Pablo y Juan Hurus $(91 * \mathrm{VC})^{19}$. De su existencia no se tenía noticia hasta la aparición de uno de los dos ejemplares de $92 \mathrm{VC}$ conservados ${ }^{20}$. Este Cancionero de Zaragoza de 1492 está ilustrado con un riquísimo programa iconográfico, aunque no uniforme, compuesto por 60 (59) grabados del ancho de columna copiados o retocados a partir de modelos foráneos, como muy bien explica M. ${ }^{a}$ Jesús Lacarra en este mismo volumen ${ }^{21}$. En concreto,

a su tío Álvar García de Santa María un Boecio que él le había prestado, como comenta María-Milagros Rivera Garretas, «Una vida en relación: Juana de Mendoza con Gómez Manrique, Isabel la Católica y Teresa de Cartagena», en AA.VV., Vidas de mujeres del Renacimiento, ed. de Ana del Campo Gutiérrez et al., Barcelona, Publicacions i Edicions, Universitat de Barcelona, 2007, pp. 103-130 (p. 127).

${ }^{18}$ Así figura en el esquema propuesto por Dorothy S. Severin y Keith Whinnom, ed. cit., p. 13, y en el trabajo de Dorothy Sherman Severin, Religious Piety and Religious Humour: Lives of Christ in Late Fifteenth-Century Castile, en An Electronic Corpus of 15th Century Castilian «Cancionero» Manuscripts, 2014, pp. 5-6. [En línea]. Enlace: $<$ https://cancionerovirtual.liv.ac.uk/studies.htm> [Consulta: 19/02/2020].

${ }^{19}$ Mercedes Fernández Valladares, «Dos ejemplares recuperados del Cancionero de Zaragoza (92VC) con sorpresa inserta: unas desconocidas Coplas del Quicumque vult y dos nuevos fragmentos de La Pasión trovada y de la Vita Christi», en Revista de Cancioneros Impresos y Manuscritos, 8 (2019), pp. 50-106.

${ }^{20}$ El título del cancionero es el de Coplas de Vita Christi de la Cena con la Passión e de la Verónica con la Resurreción de Nuestro Redentor. E las Siete angustias e siete gozos de Nuestra Señora, con otras obras mucho provechosas. Uno de los dos ejemplares, el que fuera de Salvá-Heredia, se localiza en la Biblothèque de l'École National Superieur des Beaux Arts de Paris, aunque en su catálogo erróneamente se adscribe a la edición de 1495. El otro, que perteneciera a Jovellanos, es el recientemente adquirido y digitalizado por la BNE. [En línea]. Enlace: <http://bdhrd.bne.es/viewer.vm?id=0000251821\&page=1> [Consulta: 19/02/2020]. Hasta su recuperación, se había corroborado la existencia de $92 \mathrm{VC}$ por dos manuscritos que, como bien explica Mercedes Fernández Valladares, art. cit., p. 53, tuvieron como antígrafo alguno de esos ejemplares. Se trata del cancionero ML1 de la Biblioteca Lázaro Galdiano y de la copia parcial del siglo XvIII en el ms. 18183, pieza n. 19, ff. 251r-260v, aunque solo contiene la tabla y las Coplas a la muerte de su padre de Jorge Manrique; véase M. ${ }^{a}$ Jesús Díez Garretas, «El Cancionero MN46 (BNE, Ms. 18183): del impreso al manuscrito», en Actas del XIII Congreso Internacional Asociación Hispánica de Literatura Medieval (Valladolid, 15 al 19 de septiembre de 2009). In memoriam Alan Deyermond, ed. de José Manuel Fradejas et al., Valladolid, Asociación Hispánica de Literatura Medieval, 2010, pp. 697-717.

${ }^{21}$ M. a Jesús Lacarra, «El ciclo de imágenes del Cancionero de Zaragoza en los testimonios incunables (92VC y 95VC)», véase el útil apéndice con la tabla donde se recogen los grabados de las dos ediciones en 
la $P T$ se adorna con 22 estampas que mantienen relación directa con grabados del pintor y grabador alsaciano Martin Schongauer (c. 1450-1491) y con la Pasión de Delbecq-Schreiber. Con estas xilografías las imágenes leídas de la Pasión de Cristo cobran cuerpo real y el poema se lee, pero también se ve y se recrea más fácilmente en la imaginación. En uno de estos dos ejemplares de $92 \mathrm{VC}$, concretamente en el que perteneció a la biblioteca de los jesuitas de Sevilla, después a la de Melchor Gaspar de Jovellanos y hoy en la Biblioteca Nacional de España, se han eliminado 40 hojas, entre ellas las que contienen el poema de la $P T$, quizá por la profusión y riqueza de sus estampas. La laguna ocasionada (ff. XXXV y LIIII) se ha cubierto en el caso del poema sampedrino con una ignota edición de la $P T$, con unos folios pertenecientes a una versión anterior de dicho cancionero, salido de la misma imprenta de los Hurus en 1491, pero sin estampas. El éxito alcanzado por estas dos antologías poéticas religiosas $(1491,1492)$ se corrobora con una nueva edición del cancionero publicada por Pablo Hurus en $1495^{22}$. Se trata en esta ocasión de una copia a plana y renglón de $92 \mathrm{VC} \mathrm{y,} \mathrm{por} \mathrm{tanto,} \mathrm{ilustrada} \mathrm{con} 59$ grabados (se ha eliminado la estampa n. ${ }^{\circ}$ 54, «La Muerte»). Como bien advierte Mercedes Fernández Valladares, la publicación de estos cancioneros devocionales habla de la diversificación editorial de un mismo producto en dos modalidades diferentes: una edición de lujo del cancionero con estampas $(1492,1495)$ y otra previa y más barata sin ellas ${ }^{23}$.

La $P T$ es la pieza número 3 de estos cancioneros y se introduce con el título «Comiença la Passión trobada por Diego de Sant Pedro, en la cual van enxeridas algunas razones contemplativas puestas a fin de provocar a más devoción a los que la leyeren y oyeren» $(92 \mathrm{VC})^{24}$. Como ya se ha explicado, en esta versión cancioneril impresa se ha eliminado la mención de la dama promotora y dedicataria del poema, aparecida en la manuscrita del Cancionero

\footnotetext{
los tres ejemplares conocidos. Previamente se habían referido a estos grabados Julián Martín Abad, «Cum figuris»: texto e imagen en los incunables españoles: catálogo bibliográfico y descriptivo, Madrid, Arco/ Libros, 2018, 2 vols., n. ${ }^{\circ}$ 192, y Mercedes Fernández Valladares, art. cit.

${ }^{22}$ Solo se conserva el ejemplar mútilo de Roma, Alessandrina, Inc. 382. Falta la portada, pero en el vuelto de la encuadernación se lee el título manuscrito. El ejemplar perteneció a la excelente biblioteca de Francesco Maria II della Rovere, duque de Urbino (1549-1631), quien vivió dos años en la corte de Felipe II (1565-1568); véase María Luisa Cerrón Puga, Los libros del Duque. Un recorrido por la espiritualidad y la ciencia en tiempos de la Contrarreforma. La colección de libros españoles de Francesco Maria II della Rovere (1549-1631) en el Fondo Urbinate de la Biblioteca Universitaria Alessandrina de Roma, Roma, Bagatto Libri, 2010, p. 18, n. ${ }^{\circ} 3$.

${ }^{23}$ Fernández Valladares, art. cit., p. 72.

${ }^{24} \mathrm{En} 91 * \mathrm{VC}$ se introducen ligeras variantes en la rúbrica del poema y se suprime la alusión a los oyentes de $92 \mathrm{VC}$ y $95 \mathrm{VC}$. La finalidad de las razones contemplativas insertas es «provocar a más devoción a los que la leyeren».
} 
de Oñate-Castañeda, y se brinda una edición revisada y reducida del poema de la $P T$, formada por 236 estrofas.

\section{La Pasión trobada en pliegos sueltos}

La $P T$ se publica de forma exenta en pliegos sueltos que pasan a enriquecer el corpus de pliegos poéticos pasionales o cristológicos renacentistas ${ }^{25}$. Desde el periodo incunable y hasta finales del siglo XVI, se conservan o se tiene noticia fidedigna de cinco pliegos sueltos con el poema sampedrino: [Salamanca, c. 1496], [Burgos, c. 1530], [Lisboa, c. 1530], Sevilla, 1559 y [Burgos, 1564], aunque es muy probable que existieran otros más ${ }^{26}$. A pesar de sus 20 hojas (cinco pliegos completos, en lugar de cuatro que es el formato habitual), la $P T$ se convierte en uno de los best-sellers editoriales de los pliegos de cordel y se reedita de forma sistemática a lo largo de cuatro siglos. Indiferente a modas y corrientes, fue siempre reclamo de surtidos y relacio$n e s^{27}$. En tamaño $4^{\circ}$ e impresos en letra gótica, estos pliegos presentan el texto dispuesto a doble columna y, salvo alguna excepción, todos ellos carecen de datos de impresión, quizá porque estos productos editoriales aportaban escaso prestigio al taller ${ }^{28}$. Todos los pliegos hasta ahora conocidos reproducen una versión abreviada y revisada con respecto a la manuscrita del Cancionero de Oñate-Castañeda e incluyen materiales ajenos a las ediciones incunables de los cancioneros impresos $91 * \mathrm{VC}, 92 \mathrm{VC}$ y $95 \mathrm{VC}$. De una forma u otra, en

${ }^{25}$ Véase el artículo, ya citado, de Juan Miguel Valero Moreno, «Control externo y límite genérico...»; Eva Belén Carro Carbajal, «En torno a la edición de los pliegos poéticos religiosos del siglo XVI», en Compostella Aurea. Actas del VIII Congreso de la Asociación Internacional de Siglo de Oro (AISO). Santiago de Compostela, 7-11 de julio de 2008, ed. de Antonio Azaustre Galiana y Santiago Fernández Mosquera, 2008, pp. 197-203.

${ }^{26}$ Así lo estiman Dorothy S. Severin y Keith Whinnom, ed. cit., p. 14. En el momento de la publicación de su edición y estudio, se desconocía la existencia del pliego sevillano (1559) y no se había concretado la fecha del burgalés (1564).

${ }^{27}$ Víctor Infantes, «Edición, literatura y realeza. Apuntes sobre los pliegos poéticos incunables», en Literatura hispánica, Reyes Católicos y Descubrimiento. Actas del Congreso Internacional sobre Literatura hispánica en la época de los Reyes Católicos y el Descubrimiento, ed. de Manuel Criado de Val, Barcelona, PPU, 1989, pp. 85-98 (p. 89). Los márgenes formales predefinidos del pliego se ajustan en este caso al texto literario y no a la inversa, como habitualmente sucede.

${ }^{28}$ Todos estos aspectos responden a la codificación de este género editorial, a esa «retórica formal» fijada en el periodo postincunable, ya apuntada por F. J. Norton y Edward M. Wilson, Two Spanish Verse Chap-Books, «Romançe de Amadís» (c. 1515-19), «Juyzio hallado y trobado» (c. 1510), Cambridge, University Press, 1969, pp. 5-11, y corroborada por Laura Puerto Moro «Hacia la definición de una retórica formal para el pliego suelto poético (1500-1520)», en La literatura popular impresa en España y en la América colonial: formas y temas, géneros, funciones, difusión, historia y teoría, dir. Pedro Manuel Cátedra García, ed. de María Sánchez Pérez et al., Salamanca, Seminario de Estudios Medievales y Renacentistas, 2006, pp. 543-561, y «El universo del pliego poético postincunable (del despegue de la literatura popular en castellano)», en eHumanista, 21 (2012), pp. 257-304. 
los paratextos en prosa de estos pliegos sueltos poéticos se cita el nombre de Diego de San Pedro y se menciona a la monja como impulsora y dedicataria de la composición del poema pasional. En mayor o menor medida, todos están ilustrados, aunque sus estampas no son parangonables en su calidad a las de los cancioneros zaragozanos.

El primer pliego conocido se vincula a las prensas salmantinas de Leonardo Hutz y Lope Sanz y se data $c$. $1496^{29}$, por lo que forma parte de la quincena de pliegos incunables conservados ${ }^{30}$. Un escueto título impreso en el centro de la portada con grandes letras xilográficas, La Passión trobada, sin el nombre del autor, sirve de reclamo para los lectores. La presentación del pliego bajo portada aproxima la obra a la estética libresca y es la que se impone en las sucesivas reediciones de la $P T$ en pliegos sueltos ${ }^{31}$. El vuelto de la misma se adorna con una «Estampa representando cinco escudos puestos en aspa, incluyendo en su interior una tiara, el central, y una corona, imperial y real, y un capelo, cardenalicio y episcopal, en el caso de los situados en los extremos $»^{32}$. El grabado en concreto es el mismo empleado previamente en la obra de Pedro Gratia Dei, Blasón general de todas las insignias del Universo, dedicado al sereníssimo príncipe, alto y muy poderoso rey Juan II de Portugal. Hecho en la Universidad de Salamanca por un gallego hijo del

\footnotetext{
${ }^{29}$ Londres, British Library, G.10958 = IA.52868. Konrad Haebler, Bibliografia ibérica del siglo XV. Enumeración de todos los libros impresos en España y Portugal hasta el año de 1500, con notas críticas, La Haya, etc., Martinus Nijhoff, etc., 1903-1917, 2 vols. (Edición facsímil, Madrid, Ollero \& Ramos, 1997), n. ${ }^{\circ}$ 608. Existe edición facsimilar a cargo de Antonio Pérez Gómez, «La pasión trobada de Diego de San Pedro», en Revista de Literatura, 1 (1952), pp. 147-182 (facsímil reducido, 12 hojas de lámina); Antonio Pérez Gómez, Tercera Floresta de Incunables, Valencia, 1958 («Incunables poéticos castellanos»; VIII). Lo edita Julio de Urquijo e Ibarra, «Del teatro litúrgico en el País Vasco: La Passion Trobada de Diego de San Pedro (representada en Lesaca, en 1566)», en Revue Internationale des Études Basques, 22:1 (1931), pp. 150-210 (pp. 175-210).

${ }^{30}$ La datación es la propuesta por Konrad Haebler, ob. cit., n. ${ }^{\circ} 608$, y también por Dorothy S. Severin y Keith Whinnom, ed. cit., p. 11. En general, la crítica baraja fechas próximas. Pérez Gómez, art. cit., p. 150, lo data entre 1494 y 1496; Víctor Infantes, art. cit., n. ${ }^{\circ} 239$, y Juan Carlos Conde, «Observaciones bibliográficas y literarias sobre medio pliego suelto poético», en Filologia dei testi a stampa (area iberica), ed. Patrizia Botta, con la colaboración de Aviva Garribba ed Elisabetta Vacaro, Modena, Mucchi Editore, 2005, pp. 229-240, n. ${ }^{\circ}$ 7, proponen c. 1495, y Julián Martín Abad, ob. cit., n. ${ }^{\circ} 366, c$. 1497 . El ejemplar conservado perteneció a la biblioteca de Thomas Grenville y puede ser uno de los primeros incunables españoles comprados por el bibliófilo inglés y luego donado a la British Library; véase Barry Taylor, «Thomas Grenville (1755-1846) y la bibliofilia hispánica», en Bibliofilia y Nacionalismo. Nueve ensayos sobre coleccionismo y artes contemporáneas del libro, dir. de María Luisa López-Vidriero, ed. de Pablo Andrés Escapa, Salamanca, Seminario de Estudios Medievales y Renacentistas, 2011, pp. 303-319, en concreto la entrada G. 10958, pp. 313-314.

${ }^{31}$ Cfr. con la presentación del pliego de Las Siete Angustias de Nuestra Señora la Virgen María. Fechas por Diego de Sant Pedro [Sevilla, Jacobo Cromberger, c. 1511-1515], que comienza ya con el texto, aunque sin renunciar al adorno de un grabadito en el ancho de la primera columna. [En línea]. Enlace: $<$ https://gallica.bnf.fr/ark:/12148/bpt6k8534421/f1.image> [Consulta: 19/02/2020].

${ }^{32}$ La descripción corresponde a Martín Abad, ob. cit., p. 1395, n. ${ }^{\circ}$ 366, que remite a la entrada 400.22.
} 
dicho estudio, renombre Gracia Dei, Coria, Bartolomé de Lila, 1489. Con esta estampa se explica en este libro la undécima regla de la heráldica, según la cual las armas han de ser distintas las unas de las otras para diferenciarse, y así se colige de las recogidas en el grabado:

por este escudo de la tiara con tres coronas y una cruz por la pasión qu'el trino y uno recibió por el linaje humano; el escudo de las dos coronas es del imperador por los dos estados de la iglesia cual águila de dos cabeças sinifica. El escudo de la una corona es del rey, por aquel rey soberano que de sí le dio tal renombre para reinar y regir. El escudo del capelo colorado es de cardenal, en memoria de la humanidad y pasión de Nuestro Señor, que muy alegre y por voluntad nos redimió. El capelo negro horrado en verde es de arçobispos y obispos por onestad y esperança ${ }^{33}$.

La aparición de la obra de este rey de armas de los Reyes Católicos en el entorno salmantino y la alusión a la pasión de Cristo ofrecida en la explicación de estos escudos, podría haber llevado al editor o a los impresores del pliego suelto poético a establecer la asociación y a elegir este grabado para adornar el poema. Como cierre, se elige una «Estampa, dentro de un marco de tafilete sencillo, representando el rostro de Cristo en el paño de la Verónica. $46 \times 41 \mathrm{~mm} »^{34}$. El grabadito alude al encuentro con la «dueña» que dio a Cristo su toca para limpiar su sangre y sudor («y quedó assí figurada / en aquel pobre tocado / aquella cara sagrada», h. c1v) y parece remedar el que en los cancioneros zaragozanos (92VC y 95VC) introduce las «Coplas que hizo fray Íñigo de Mendoza a la Verónica. Fabla la Verónica», que siguen a la $P T$. En la viñeta salmantina, mucho más tosca, no se representa la Verónica, tan solo el tocado con la faz de Cristo. Aunque formalmente el pliego se caracteriza por su austeridad iconográfica, las dos xilografías incluidas muestran ya un deseo por parte de los impresores de alejarse de la tradición «anicónica» de la hagiografía castellana medieval y de convertir el material piadoso en producto comercial ${ }^{35}$.

${ }^{33}$ Pedro Gracia Dei, Blasón general de todas las insignias del Universo, edición foto-litográfica, Madrid, Librería de M. Murillo, 1882, s. p. [En línea]. Enlace: <http://bdh-rd.bne.es/viewer. vm?id=0000078537 \&page $=1$ ) $>$ [Consulta: 19/02/2020].

${ }^{34}$ Martín Abad, ob. cit., n. ${ }^{\circ}$ 366, pp. 1395-1396.

${ }^{35}$ Es lo que sucede también con la transformación del Flos sanctorum en la imprenta que, si bien en muchos aspectos respeta la impronta de la tradición manuscrita en el producto editorial, la novedad de las estampas cambia radicalmente el aspecto del libro, aunque no todavía en el primer incunable, como explica Fernando Baños Vallejo, «La transformación del Flos sanctorum castellano en la imprenta», en Vides medievals de sants: difusió, tradició i llegenda, ed. de M. Garcia Sempere y M. À. Llorca Tonda, Alicante, Institut Interuniversitari de Filologia Valenciana, 2012, pp. $65-97$ (p. 72). 
Frente al resto de testimonios hasta ahora analizados, este pliego salmantino ofrece como novedad doce coplas precedidas del siguiente epígrafe:

Una devota monja rogó a Diego de Sant Pedro que trobasse la passión de nuestro Redentor, a la cual él quería tanto que todo su pensamiento era en qué y cómo la havía de servir, y aunque insuficientia grand embarazo le pusiesse a no fazello, forzando su voluntad, por su mandado hovo de trovar la dicha Passión. E ante que la comenzasse embiole las coplas siguientes (h. Aijr) ${ }^{36}$.

Como ya se ha comentado, por su valor profano y tono amoroso, estos versos no figuran en ninguno de los testimonios incunables de los cancioneros $92 \mathrm{VC}$ y $95 \mathrm{VC}$ y solo se repiten en el pliego burgalés $c$. 1530. Tras las coplas, el poema pasional se introduce con un nuevo íncipit en prosa donde se indica que su finalidad es despertar la devoción entre sus lectores y oyentes: «Comienza la Passión trobada por el dicho Diego de Sant Pedro, en la cual van enxeridas algunas razones contemplativas, puestas a fin de provocar a más devotión a los que la leyeren e oyeren» (h. Aiijr), apelando a un público amplio y popular al que el poema ha de llegar también a través de la voz.

Una nueva edición de la $P T$ en pliego suelto se publica, sine notis, en Burgos hacia 1530-1540, en las prensas de Juan de Junta ${ }^{37}$. Como la anterior, incluye la dedicatoria y las coplas dirigidas a la devota monja de la que Diego de San Pedro dice estar enamorado. La diferencia más notable con respecto al pliego salmantino es su profusa ilustración, 22 grabados xilográficos que recuerdan inevitablemente los del Cancionero zaragozano de 1492 y 1495, tanto en su número como en su figuración (aunque de inferior calidad) y distribución. Como indica Mercedes Fernández Valladares, pertenecen a una serie de estampas del ciclo de la Pasión formada por 20 entalladuras (de 54

${ }^{36}$ De este pliego (o de algún otro también temprano) con la $P T$ se copian algunos versos y estrofas en el cancionero compuesto en Salamanca (c. 1500) (SA9), Biblioteca Universitaria de Salamanca, ms. 2762. «En f. 152v, una mano post. copia algunos versos y estrofas de la Pasión trobada de Diego de San Pedro: Señora si lo mandastes / porque sabre bien fazello...; El nuevo navegador / siendo de tierra alongado...»; véase Catálogo de Manuscritos de la Biblioteca Universitaria de Salamanca, II. Manuscritos 1680-2777, ed. de Oscar Lilao Franca et al., Salamanca, Ediciones de la Universidad de Salamanca, 2002, p. 1133. Corresponden exactamente a la segunda parte de la cuarta copla.

${ }^{37}$ Solo se conoce el ejemplar de Londres, BL, C. 63.f.12. La datación procede de la información personal de F. Norton brindada a Whinnom, como se indica en Severin y Whinnom, ed. cit., p. 12. Existe edición facsimilar en Pliegos Poéticos Españoles de la British Library, Londres (Impresos antes de 1601). Tomo II. Homenaje a Sir Henry Thomas, estudio de Arthur L.-F. Askins, Madrid, 1989, pp. 792-827, n. ${ }^{\circ}$ 42. Algunas imágenes de este ejemplar londinense están coloreadas en ocre y rojo. La identificación y datación de Norton (Burgos, $c$. 1530, por Juan de Junta) ha sido confirmada por Mercedes Fernández Valladares, La imprenta en Burgos (1501-1600), Madrid, Arco/Libros, 2005, 2 vols., a quien se debe una detallada descripción, n. $^{\circ} 336$. 
x $43 \mathrm{~mm}$ ), enmarcadas por doble filete, ocupando el ancho de la columna ${ }^{38}$. Para ilustrar la portada se ha elegido una xilografía de la Última Cena, a cuyo pie figura La Passión de nuestro redemptor y salvador Jesucristo, trobada por Diego de Sant Pedro, un título ligeramente ampliado con respecto al testimonio anterior y con la mención de su autor. La estampa de la Última cena, anuncio de la Pasión, aunque de motivo similar a la que en los cancioneros 92VC y 95VC adorna un pasaje de unas coplas de la Vita Christi de fray Íñigo de Mendoza, no puede considerarse una copia. El pequeño grabadito, encuadrado en doble filete, se ve realzado por una rica orla xilográfica, adornada con jarrones, motivos vegetales, grifos y un bucráneo. En esta estampa de la Última Cena, Cristo aparece ubicado en el centro de una mesa semicircular, identificado por el nimbo crucífero, con una mano bendiciendo y con la otra entregando un bocado a Judas ( $\sin$ nimbo y con la bolsa de las treinta monedas escondida tras su espalda), signo del anuncio de la traición. Entre los doce apóstoles destaca la figura de san Juan, representado como imberbe y, como discípulo más cercano de Jesús, recostado sobre su seno ${ }^{39}$. Curiosamente, la primera imagen interior repite la estampa de la Última Cena, pero con una xilografía diferente ${ }^{40}$. En el afán de emular quizá la rica ilustración cancioneril (92VC y 95VC), el pliego se adorna con una serie de grabaditos mucho más rústicos que cumplen, sin embargo, la misma finalidad de ofrecer un discurso visual en paralelo al escrito que refuerza el mensaje religioso, ayuda a la memorización y a la contemplación perseguida. Aunque la presencia de la imagen es consustancial al pliego suelto religioso y su componente taumatúrgico, pocos son los pliegos de las tres primeras décadas del siglo XVI con tantas imágenes ${ }^{41}$.

${ }^{38}$ Fernández Valladares, ob. cit., pp. 639-640, n. ${ }^{0} 336$. De acuerdo con su descripción, representan: «la oración en el huerto, la Última Cena, la traición de Judas, Jesús ante Anás, Jesús ante Caifás, Jesús ante Pilato (y después el mismo grabado para representar a Jesús ante Herodes), la flagelación, la burla de Jesús como Rey de reyes, la coronación de espinas, Ecce Homo, Pilato se lava las manos, la subida al Calvario, la Verónica con la Santa Faz (repetido otra vez), Cristo es clavado en la Cruz, Cristo crucificado, Cristo crucificado con la Virgen y San Juan al pie de la Cruz, Cristo crucificado entre los ladrones, la lanzada de Longino, el Descendimiento y el Santo entierro», p. 640.

${ }^{39}$ Véase María Rodríguez Velasco, «Tipos iconográficos de la Última Cena y simbolismo eucarístico en las imágenes de la Edad Media», en Revista Digital de Iconografia Medieval, 16 (2016), pp. 119-142 (p. 122); Louis Réau, Iconografia del Arte Cristiano. Iconografia de la Biblia-Nuevo Testamento, Barcelona, Ediciones del Serbal, 1996, pp. 426-430.

${ }^{40}$ No es tampoco la misma que la que adorna La Passión del eterno príncipe Jesucristo en romançe, de Jean Gerson, un texto en prosa publicado en Burgos, por Fadrique de Basilea, en ¿1493?, h. vjr.; véase el ejemplar conservado en la Biblioteca Pública de Boston. [En línea]. Enlace: $<$ https://archive.org/details/lapassiondeleter00biel/page/n4/mode/2up> [Consulta: 19/02/2020].

${ }^{41}$ Compárese, por ejemplo, con los cuatro pliegos del ciclo la Pasión del periodo postincunable descritos por Laura Puerto, «El universo...», art. cit., pp. 290-291. 
Hacia 1530 se publica también otro cuadernillo con la $P T$ en tierras portuguesas, donde la capacidad de leer obras en español no era inusual entre el público alfabetizado ${ }^{42}$. Como los anteriores, el pliego suelto se edita sin indicación tipográfica alguna y ha sido identificado por la crítica como impreso en Lisboa, por Germão Galharde ${ }^{43}$. Este impresor, de origen francés, comienza a trabajar en Lisboa y Coimbra en 1519, heredando materiales del impresor alemán Valentim Fernandez y del italiano João Pedro de Bonhomini ${ }^{44}$. En la década de 1530, en la que supuestamente imprime la $P T$ sampedrina, había abierto taller en el Monasterio de Santa Cruz de Coimbra a petición del rey João III. Como los anteriores, el pliego consta de 20 hojas, está impreso en letra gótica y el texto dispuesto a doble columna, salvo en la última hoja, ocupada por un grabadito del Santo entierro seguido de la quintilla final del poema. La impresión no es tan cuidada como la burgalesa antes comentada y el texto no se muestra tan aireado, pues no siempre se incluye separación entre las estrofas ni se añade el calderón demarcativo de las mismas. En esta edición se eliminan las coplas a la devota monja y, como ya se ha dicho, los dos íncipit en prosa que en pliegos anteriores preceden a los versos amorosos dedicados a la religiosa y al poema propiamente dicho, se funden en uno solo, justificando la inclusión de las «razones contemplativas» insertas en el poema como conformes a la religión y regla de la monja. En el interior del poema, se suprime una de las estrofas del parlamento de Jesús con el ángel («Pero mucho te encomiendo») ${ }^{45}$ y se imprime por primera vez una copla de las que Severin y Whinnom llaman estrofas adicionales de la versión incluida en el Cancionero de Oñate Castañeda, en concreto la por ellos numerada estrofa 214A («San Juan con mucha humildad»), correspondiente al momento en el que la Virgen se reencuentra con su hijo crucificado a punto de expirar y san Juan recrimina a los judíos los insultos hacia ella ${ }^{46}$.

\footnotetext{
${ }^{42}$ F. J. Norton, A Descriptive Catalogue of Printing in Spain and Portugal 1501-1520, Cambridge, University Press, 1978, p. 493.

${ }^{43}$ Solo se conserva el ejemplar de Nueva York, Hispanic Society. De nuevo la identificación del pliego fue proporcionada personalmente por F. Norton a Whinnom, véase Severin y Whinnom, ed. cit., p. 12. Clara Louisa Penney, Printed Books 1468-1700, New York, The Hispanic Society of America, 1965, p. 496, sugiere ¿Sevilla, Juan Varela de Salamanca, c. 1516?, propuesta que repite USTC sin citar la procedencia. Antonio Rodríguez Moñino, Diccionario bibliográfico de pliegos sueltos poéticos (siglo XVI), Madrid, Castalia, 1970, n. ${ }^{\circ}$ 530, no aporta datación alguna.

${ }^{44}$ Además de la información brindada por Norton, ob. cit., pp. 500-501, estudia su producción Helga Jüsten, «Algumas achegas sobre o material tipográfico da oficina de Germão Galharde e de sua viúva (1519-1565)», en Fragmenta Historica, 2 (2014), pp. 11-38, aunque no incluye el pliego de la $P T$.

${ }^{45}$ En Severin y Whinnom, ed. cit., p. 125 , corresponde a la n. ${ }^{\circ} 41$.

${ }^{46}$ En el stemma propuesto por Severin y Whinnom, ibidem, p. 13, esta edición derivaría de una primera versión impresa, pues «si bien conserva varias lecciones indudablemente primitivas, también está
} 


\section{M. ${ }^{a}$ Carmen Marín PinA}

Al igual que el pliego burgalés, está profusamente ilustrado, en este caso con 17 pequeñas xilografías todas ellas vinculadas al ciclo de la Pasión de Cristo que no ocupan la totalidad del ancho de columna ${ }^{47}$. Para adornar la portada se elige una estampa de la crucifixión, enmarcada por una orla de cuatro piezas decoradas con motivos vegetales entrelazados en jarrones, un ángel alado y la letra $\mathrm{P}$ invertida (figura 1). La crucifixión muestra la imagen de Jesús clavado en la cruz, goteando sangre de sus manos y pies y flanqueado a ambos lados por la Virgen María y por san Juan. Se trata de una representación de la crucifixión más devocional, centrada en la imagen del crucificado, frente a otras de carácter más narrativo que incluyen muchas más figuras y elementos ${ }^{48}$. En 1531 Germão Galharde emplea el mismo grabado en otro libro salido de las prensas del monasterio de la Santa Cruz de Coimbra antes citado, en concreto en el interior de la obra de Lourenco Justiniano, Ho liuro da regra \& perfeyção da cõuersaçã dos monges (figura 2). La xilografía procede de la oficina del impresor de origen italiano João Pedro de Bonhomini, quien lo había usado ya en la impresión de Este he o liuro e legenda dos santos marres, Lisboa, $1513^{49}$.

Quizá habría que replantearse si el lugar de impresión del pliego no fuera Lisboa sino Coimbra y que saliera del taller del mencionado monasterio, donde se imprimen obras religiosas. La supresión de las comprometidas coplas amorosas a la devota monja se explicaría por el deseo de que el pliego tuviera un inequívoco valor religioso y devocional o bien porque la fuente

plagado de errores, así que debieron intervenir entre la primera edición impresa y esta una serie de impresiones, probablemente pliegos sueltos, ahora perdidas» (p. 14).

${ }^{47}$ Los grabados interiores representan: la Última Cena, la oración en el huerto, la traición de Judas, Jesús ante Anás, Jesús ante Herodes, la flagelación, la burla de Jesús como Rey de reyes, Pilato se lava las manos, la subida al Calvario, la Verónica con la Santa Faz, Cristo es clavado en la cruz, Cristo crucificado rodeado a ambos lados por un grupo de soldados que echan a suertes sus ropas (del personaje de la izquierda sale una filacteria con unas letras), Cristo crucificado flanqueado a su izquierda por la Virgen y la Magdalena arrodilla a la pies de la cruz y a la derecha por unos soldados, Cristo crucificado entre los ladrones, Cristo crucificado con el centurión que le moja la cara con vinagre a la izquierda y a la derecha la Virgen María arrodillada y tras ella san Juan y, como cierre, el Santo entierro.

${ }^{48}$ Laura Rodríguez Peinado, «La Crucifixión», en Revista Digital de Iconografia Medieval, 4 (2010), pp. 29-40 (p. 31). La estampa de la crucifixión de Durero, reproducida, por ejemplo, en Speziale Opus Missarum, de Johann Grüninger, 1493, deja su impronta en otras españolas como las citadas por Fernando Checa Cremades «La imagen impresa en el Renacimiento y el manierismo», en Summa artis. Historia general del arte. Vol. XXXI. El grabado en España (Siglos XV al XVIII), Madrid, Espasa-Calpe, 1996, pp. 11-200 (p. 60), a las que podría sumarse la ahora mencionada.

${ }^{49} \mathrm{La}$ edición puede verse en la Biblioteca nacional digital de Portugal (RES-166-A). [En línea]. Enlace: $<$ http://purl.pt/16678/1/index.html\#/8/html $>$ [Consulta: 19/02/2020]. La identificación de su procedencia del taller de João Pedro de Bonhomini se debe a Helga Jüsten, art. cit., p. 15. La parte inferior de la orla que enmarca la crucifixión figura en otro impreso de Galharde, Incipit officiu[m] angeli custodis regni ciuitatis velloci, Olixboñen [sic], 1529, y la pieza lateral, con la letra P invertida, procede del material heredado de Valentim Fernandes, quien la había empleado en la Grammatica Pastrane, Lisboa, 1497. 


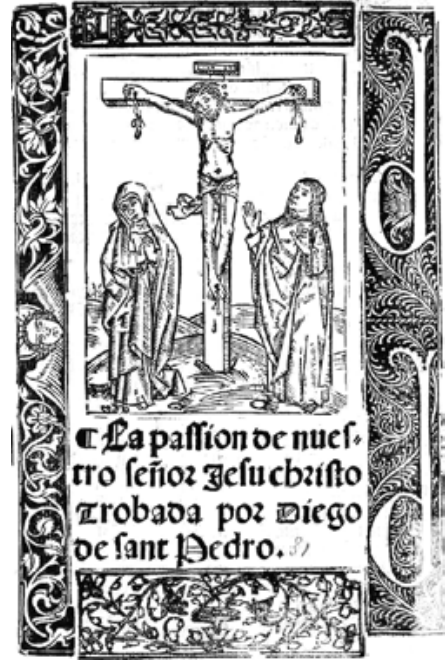

Fig. 1. [Lisboa, Germão Galharde, c. 1530]. (C) Hispanic Society.

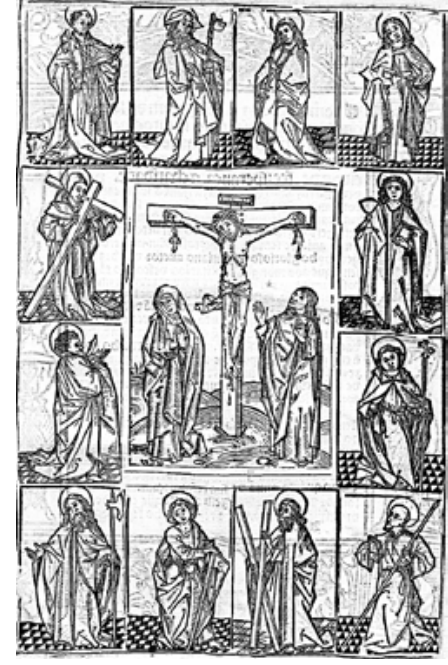

Fig. 2. Ho liuro da regra \& perfeyção da cõuersaçã dos monges, 1531. (C) Biblioteca Nacional de Portugal.

de Galharde fuera un pliego suelto con las coplas ya omitidas. El modelo pudo ser una edición sevillana hoy perdida por las similitudes que guarda con el pliego seguidamente comentado (Sevilla, 1559) y porque algunos de los grabaditos interiores son copias de viñetas con escenas de la vida de Cristo utilizadas por Jacobo Cromberger en sucesivas ediciones del Retablo de la vida de Cristo de Juan de Padilla (Sevilla, 1510, 1511, 1518, 1258) ${ }^{50}$. Es el caso, por ejemplo, de la escena de la subida al Calvario (figuras 3 y 4 ) o la de Pilato lavándose las manos (figuras 5 y 6 ).

\footnotetext{
${ }^{50}$ Se trata de copias de los grabaditos de la serie WC 481-504, según la nomenclatura de Clive Griffin, The Crombergers of Seville: the History of a Printing and Merchant Dynasty, Oxford, Clarendon Press, 1988, microfichas, pp. 1468-1470. Son las estampitas WC: 489, Jesús ante Anás; WC: 491, la burla como Rey de reyes; WC: 495: Pilato se lava las manos; WC: 496, la subida al calvario; WC: 497, Cristo crucificado; WC: 498, Cristo crucificado con la Magdalena arrodillada y agarrada a la cruz; WC: 499, Cristo crucificado entre los ladrones y WC: 501, los soldados sortean sus ropas. Aunque algunas de las viñetas se renuevan en las diferentes ediciones, las comentadas pueden verse en la edición sevillana del Retablo de la vida de Cristo, ¿Sevilla, 1518?, ejemplar de la Biblioteca Històrica de la Universitat de València, BH R-2/093(2). [En línea]. Enlace <http://weblioteca.uv.es/cgi/view7.pl?sesion=202002240749141933 $0 \&$ source $=$ uv_im_i19909822\&div $=50 \&$ mini $=1 \&$ mend $=60>$ [Consulta: 19/02/2020]. O en la edición de Sevilla, 1528: [En línea]. Enlace: $<$ https://books.google.es/books?id=3K7kgTSFaIC\&hl=es\&pg=PA1\#v $=$ onepage $\& q \& \mathrm{f}=$ false $>$ [Consulta: 19/02/2020]. No hay que olvidar que Jacobo Cromberger colabora en un proyecto editorial con Fernandes y Bonhomini impulsado por el rey Manuel de Portugal y que fallece en tierras portuguesas, véase Norton, ob. cit., pp. 494-495.
} 


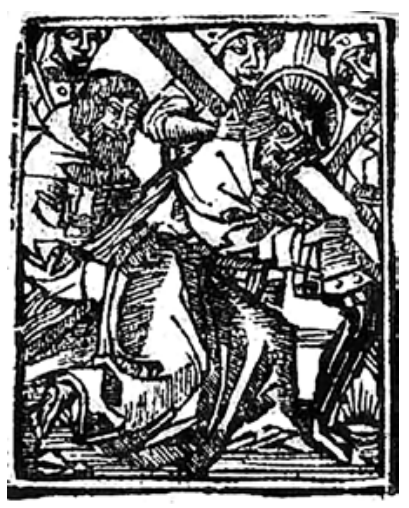

Fig. 3. La Pasión trobada, [Lisboa, c. 1530]. (C) Hispanic Society.

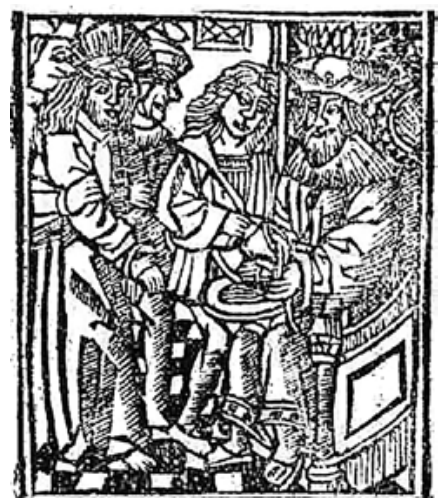

Fig. 5. La Pasión trobada, [Lisboa, c. 1530]. (C) Hispanic Society.

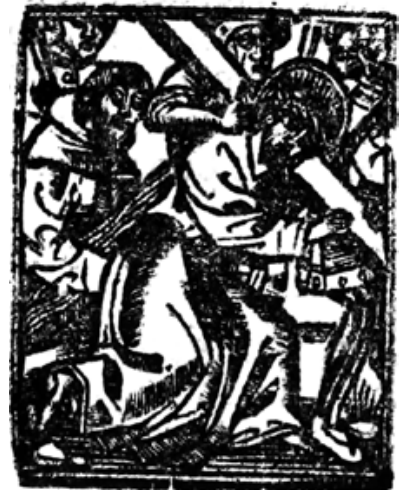

Fig. 4. Retablo de la vida de Cristo, ¿Sevilla, 1518? (C) Biblioteca Històrica, Universitat de València.

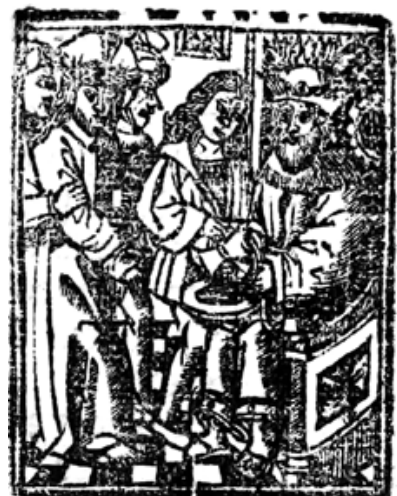

Fig. 6. Retablo de la vida de Cristo, ¿Sevilla, 1518 ? (C) Biblioteca Històrica, Universitat de València.

Cierra este conjunto de pliegos sueltos renacentistas de la $P T$ con ejemplar conservado el publicado en Sevilla, en 1559, recientemente hallado ${ }^{51}$. Compuesto por 18 hojas, es el único que presenta colofón y en él se lee: «Fue impressa la presente obra en la muy noble e muy leal ciudad de Sevilla, en casa de Juan Gómez, impressor de libros. En cal de la Sierpe. Acabose en el año de mil e quinientos e cincuenta y nueve». El impresor, Juan Gómez, es un naipero establecido en Sevilla, cuya producción parece reducirse al poema

${ }^{51}$ Solo se conoce el ejemplar de la Biblioteca de Viena, Österreichische Nationalbibliothek, 26634B Alt Mag NC. [En línea]. Enlace: $<$ http://digital.onb.ac.at/OnbViewer/viewer.faces?doc=ABO_+Z167062409> [Consulta: 19/02/2020]. El primero en describirlo es Arcadio Castillejo Benavente, La imprenta en Sevilla en el siglo XVI (1521-1600), ed. Cipriano López Lorenzo, Córdoba, Universidad de Córdoba, Universidad de Sevilla, 2 vols., 2019, vol. II, n. ${ }^{\circ} 816$. 
sampedrino, a la Relación muy verdadera de la venida de su Magestad del muy alto rey don Ppelipe (sic) de Pedro de Estrada (Sevilla, 1559) y poco más ${ }^{52}$. Se trata sin duda de un producto editorial mucho más humilde que el resto de los pliegos de la $P T$. Con el fin de abaratar costes, se ha reducido la extensión de hojas (18 hojas, en lugar de 20), lo que conlleva la supresión de algunos epígrafes y estrofas y muchas menos ilustraciones (en total, 4 grabados) ${ }^{53}$. Se respeta, sin embargo, la presentación del pliego con portada, adornada con una xilografía de la crucifixión a cuyo pie figura el título, La passión de nuestro señor Jesuchristo trobada, del que des-

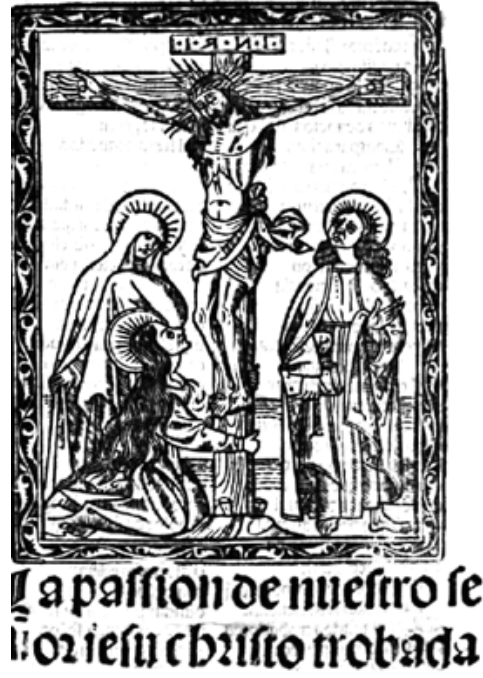

Fig. 7. La Pasión trobada, Sevilla, 1559. (C) Österreichische Nationalbibliothek. aparece el nombre de Diego de San Pedro (figura 7). La referencia del autor se respeta, en cambio, en el íncipit resultado, como en el cuadernillo portugués, de la fusión de los íncipit en prosa de los pliegos anteriores. Se mantiene, por tanto, la mención de la monja peticionaria («a pedimiento e ruego de una monja, a la cual era mucho en cargo»), pero no las coplas amorosas.

Dentro de su humildad, el pliego no renuncia a adornar el texto con grabados. En la portada aparece una estampa de la crucifixión de Cristo enmarcada en una orla completa decorada con motivos vegetales. La xilografía representa a Cristo crucificado flanqueado a cada lado por la Virgen María y san Juan y con María Magdalena, de larga y exuberante melena, arrodillada y agarrada a la cruz mostrando su dolor (figura 7). El grabado procede de la imprenta hispalense y lo había utilizado muchos años antes (encuadrado en

\footnotetext{
${ }^{52}$ Las noticias sobre este impresor de obras menores son escasas. Véase Juan Delgado Casado, Diccionario de impresores españoles: (siglos XV-XVII), Madrid, Arco/Libros, 1996, 2 vols., n. ${ }^{\circ} 343$; M. ${ }^{\text {a del }}$ Carmen Álvarez Márquez, La impresión y el comercio de libros en la Sevilla del quinientos, Sevilla, Universidad de Sevilla, 2007, p. 4; Pedro M. Cátedra, «Notúnculas sobre impresores viejos y nuevos del siglo XVI», en El libro antiguo español. VI. De libros, librerías, imprentas y lectores, dir. Pedro M. Cátedra y María Luisa López-Vidriero, ed. de Pablo Andrés Escapa, Salamanca, Ediciones de la Universidad de Salamanca, Seminario de Estudios Medievales y Renacentistas, 2002, pp. 67-72 (pp. 69-70), y Castillejo Benavente, ob. cit., II, pp. 108-109. Para otras impresiones a su nombre, véase Alexander S. Wilkinson, Iberian Books. Books Published in Spanish or Portuguese or on the Iberian Peninsula before 1601, Leiden-Boston, Brill, 2010, n. ${ }^{\circ} 8536,8537$ y 18723.

${ }^{53}$ Con respecto a los pliegos anteriores, se omiten las coplas «Algunas dueñas miravan» y «Dezían para qué parió»», que en la citada edición de Severin y Whinnom, p. 144, corresponden a las coplas 83 y 84 .
} 
la misma orla) Jacobo Cromberger para ilustrar la obra Liturgias, Dominicos, Procesionario (Sevilla, 1519) ${ }^{54}$. El carácter invertido del «título» de la cruz «INRI» hace pensar que el grabado sea copia de otra plancha. En su interior el pliego está ilustrado por tres grabaditos de diferente factura que no llegan a ocupar el ancho de la columna y representan la cena de Emaús, aunque quiere hacer las veces de la última Cena, la oración de Jesús en el huerto (con el doble filete que lo enmarca muy desgastado) y la crucifixión, con la Virgen María y san Juan a ambos lados de Cristo en la cruz (al fondo del mismo quiere advertirse un paisaje). Es posible que Juan Gómez tuviera como fuente una edición sevillana anterior perdida, salida de la imprenta de Juan Varela de Salamanca, al que adeudaba dinero por la compra de papel viejo, o del taller de los Cromberger, algunos de cuyos materiales parece aprovechar en la impresión de este pliego. Además del grabado de la portada, la viñeta interior con la representación de la cena de Emaús con Jesús resucitado (figura 8), pertenece también a una de las series de grabaditos de la Pasión usada por Jacobo Cromberger en obras tempranas como la Passio domini nostri Jesu Christi carmine heroico composita (Sevilla, c. 1506) de Adam de Montaldo y el ya citado Retablo de la vida de Cristo de Juan de Padilla (¿Sevilla, c. 1518?) (figura 9) ${ }^{55}$. En este caso, sin embargo, la viñeta no es una copia.

Lo más probable es que no sea esta la primera edición sevillana de la $P T$. Cuesta creer que los Cromberger (o Juan Varela de Salamanca) no imprimieran este poema pasional cuando, hacia 1511-1515, habían publicado en pliego suelto Las Siete Angustias de Nuestra Señora la Virgen María. Fechas por Diego de San Pedro, por no hablar de otras obras de Diego de San Pedro ${ }^{56}$. Este pliego de la $P T$ de 1559 guarda muchas similitudes con el publicado por Germão Galharde (c. 1530), entre ellas la inclusión de la mencionada copla del Cancionero de Oñate-Casteñada, la numerada por Severin y Whinnom como estrofa 214A («San Juan con mucha humildad»), que no aparece en otras versiones impresas ${ }^{57}$.

\footnotetext{
${ }^{54}$ La reproduce Clive Griffin, Los Cromberger. La historia de una imprenta del siglo xVI en Sevilla y Méjico, Madrid, Ediciones de Cultura Hispánica, 1991, p. 256, fig. 82, así como en The Crombergers of Seville, ob. cit., microfichas, p. 1439, y corresponde al grabado WC: 357 . Una temprana estampa de la crucifixión con la figura de Magdalena arrodillada a los pies de la cruz se encuentra en la obra de Bernat Fenoller, Historia de la Passió de N. S. Jesu Christi en cobles (Valencia, 1493), ya citada.

${ }^{55}$ Se trata de la viñeta catalogada por Griffin como WC: 569 y se integra en una de las diferentes series de pequeñas xilografías del ciclo de la Pasión, en concreto la WC: 567-572; véase Clive Griffin, The Crombergers of Seville, ob. cit., microfichas, p. 1481. Como los anteriormente mencionados, puede verse en la edición del Retablo de la vida de Cristo (¿Sevilla, 1518?) citada en la nota 50 de este trabajo.

${ }^{56}$ Norton y Wilson, ob. cit., n. ${ }^{\circ} 80$, p. 29 ; Askins e Infantes, ob. cit., n. ${ }^{\circ} 532$, pp. 468-469.

${ }^{57}$ Severin y Whinnom, ed. cit., p. 217. Tal estrofa estaría ubicada entre las 209 y 210 de su edición. El texto de esta edición sevillana presenta muchas lecturas comunes con la edición de Germão Galharde, pero también variantes y algún error significativo.
} 


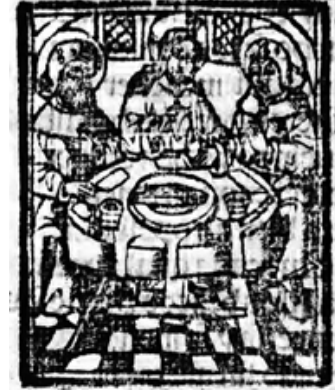

Fig. 8. La Pasión trobada, Sevilla, 1559. (C) Österreichische Nationalbibliothek.

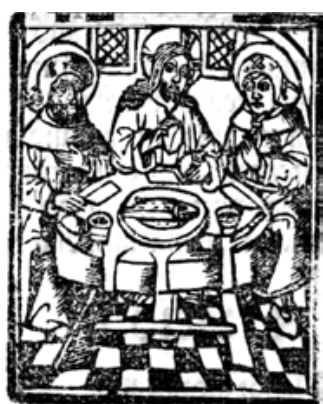

Fig. 9. Retablo de la vida de Cristo, ¿Sevilla, 1518? (C) Biblioteca Històrica, Universitat de València.

Es posible que estas dos ediciones deriven, por tanto, de una edición sevillana perdida. Considerando esta posibilidad, los ejemplares hallados en el inventario de Juan Cromberger en 1540 podrían ser también de una edición salida de sus prensas ${ }^{58}$. La calidad del papel y de la impresión, así como los grabados de acarreo que adornan este pliego hispalense de la $P T$ de 1559 evidencian que la obra se ha convertido en producto editorial de consumo popular.

Aunque no se conserva ejemplar, la crítica reconoce la existencia de otro pliego de la $P T$ impreso en Burgos, en 1564. Se corrobora a partir de un documento en el cual se indica que los vecinos del pueblo navarro de Lesaca, en 1566, piden permiso para representar la Pasión a partir de una edición del poema de Diego de San Pedro hasta la fecha desconocida: «y para ello tienen vna emprenta dela dha pasión que es ympresa en la ciudad de burgos del Reyno de Castilla segun porla dha emprenta paresce ympresa por diego de Sanpedro con licencia el año de mill e quinyentos sesenta y quatro» ${ }^{59}$. La utilización de la $P T$ como texto teatral no es de extrañar ya que gran parte de la originalidad y éxito del poema reside en sus cualidades y estilo dramático, parejo al de los sermones de impronta franciscana, de modo que podría pasar

\footnotetext{
${ }^{58}$ «290 pasiones» registra Clive Griffin, «Inventario del almacén de libros del impresor Juan Cromberger: Sevilla, 1540», en El libro antiguo español, IV: coleccionismo y bibliotecas (siglos XV-XVIII), ed. de María Luisa López-Vidriero, Pedro M. Cátedra, María Isabel Hernández González, Salamanca, Universidad de Salamanca, Sociedad Española de Historia del Libro, 1998, pp. 257-373, en el mencionado inventario y sugiere que podría tratarse de la edición burgalesa de la Pasión trobada de Diego de Pedro impresa por Juan de Junta, c. 1540 (p. 297, n. ${ }^{\circ}$ 139). En el inventario de Juan de Ayala, transcrito por Antonio Blanco Sánchez, «Inventario de Juan de Ayala, gran impresor toledano (1556)», BRAE, 67 (1987), pp. 207-250 (p. 218, 224, 230, 231, 233), se contabilizan más de 1300 Pasiones, algunas de las cuales podrían referirse también al poema sampedrino.

${ }^{59} \mathrm{La}$ edición se fecha con exactitud a partir del documento Lesaca, editado por Julio de Urquijo e Ibarra, art. cit., p. 164, y que reproduce parcialmente también Mercedes Fernández Valladares, ob. cit., p. 890, n. $^{\circ} 527$.
} 


\section{M. ${ }^{a}$ Carmen Marín PinA}

por una obra religiosa teatral ${ }^{60}$. Contribuye a ello el uso frecuente del diálogo, la descripción de acciones y la carencia de interrupciones dogmáticas. No sorprende por ello que la PT y Las Siete Angustias de Nuestra Señora sean algunas de las fuentes seguras de inspiración del inconcluso Auto de la pasión (c. 1486) de Alonso del Campo, una pieza teatral representativa del teatro procesional castellano más primitivo, destinada, posiblemente, a las festividades del Corpus en Toledo ${ }^{61}$. Tampoco que la parte final de la versión extensa del poema sampedrino contenida en el Cancionero de Oñate-Castañeda se considere uno de los intertextos del Auto de la Pasión (1514) de Lucas Fernández $z^{62}$, y que, fuera de las pasiones dramáticas, la $P T$ pudiera servir de referente textual y estructural para los dos actos finales de la Tragicomedia de Calisto y Melibea ${ }^{63}$.

\section{Conclusiones}

En el conjunto de la poesía pasional de uso litúrgico o dramático, la $P T$ de Diego de San Pedro es sin duda una de las composiciones que alcanzó mayor popularidad y longevidad. Manuscrita e impresa, recopilada en cancioneros o editada de forma exenta en pliegos sueltos, la obra desafía al paso del tiempo acomodándose en cada momento a su medio de difusión. Sin entrar en su complejísima transmisión textual, los testimonios conservados revelan mayoritariamente una versión abreviada del poema que es la que llega a la imprenta y en ella alcanza una rentable diversificación editorial, pensada para diferentes tipos de público. Aunque se desconoce si la $P T$ inicia su andadura en solitario o en compañía, el primer testimonio conservado la incluye en una obra colectiva. En las diferentes ediciones del Cancionero de Zaragoza (c. 1491, 1492 y 1495), el poema sampedrino es una pieza más de la recopilación

${ }^{60}$ Véase Pedro M. Cátedra, «De sermón y teatro, con el enclave de Diego de San Pedro», en The Age of the Catholic Monarchs, 1474-1516. Literary Studies in Memory of Keith Whinnom, ed. de Alan Deyermond y I. Macpherson, Liverpool, University Press, 1989, pp. 6-35.

${ }^{61}$ Alonso del Campo copia, retoca y revuelve los materiales sampedrinos, como bien explican Alberto Blecua, «Sobre la autoría del Auto de la Pasión", en Homenaje a Eugenio Asensio, Madrid, Gredos, 1988, pp. 79-112, y Juan Leyva, «El Auto de la Pasión y su adaptación de la Pasión trovada y Las siete angustias desde el punto de vista de las circunstancias de su representación», en Caballeros, monjas y maestros en la Edad Media, ed. de Lillian von der Walde et al., México, Universidad Nacional Autónoma de México, El Colegio de México, 1996, pp. 231-249.

${ }^{62}$ Dorothy Sherman Severin, «Lucas Fernández and two Intertexts: Fernando de Roja's La Celestina and Diego de San Pedro's Passión trobada», en eHumanista/Conversos, 2 (2014), pp. 86-93.

${ }^{63}$ El poema de Diego de San Pedro pudo ser el modelo para el contrafactum pasional del desenlace celestinesco y el planto de la Virgen María, el del lamento de Pleberio, como sugiere Amaranta Saguar García, «Diego de San Pedro en Celestina: más allá de Cárcel de amor», en Dicenda. Cuadernos de Filología Hispánica, 30 (2012), pp. 127-139. 
y se contextualiza en el conjunto de la poesía religiosa más representativa del momento. En el seno del cancionero la $P T$ comienza su visualización, por primera vez se viste con estampas de la vida de Cristo que iluminan y complementan las elocuentes imágenes verbales salidas de la pluma de Diego de San Pedro. El poema cobra, sin embargo, vida propia en los pliegos sueltos y la andadura en solitario iniciada en la época incunable se prolonga hasta bien entrado el siglo XIX, momento en el que de nuevo vuelve a ser incluida en una recopilación poética ${ }^{64}$. Su considerable extensión (20 hojas), su presentación bajo portada y su dedicatoria (a la devota monja) confieren a este nuevo producto editorial una apariencia o estética libresca. En los pliegos sueltos analizados -[Salamanca, c. 1496]; [Burgos c. 1530-1540]; [Lisboa, c. 1530]; Sevilla, 1559 y [Burgos, c. 1564]-, el poema se acompaña de dos breves paratextos en prosa en los que aparece la figura de la devota monja peticionaria-dedicataria del poema, ausente en los cancioneros. Su mención, como amada del poeta (de ahí el envío de los comprometidos versos amorosos) o como conocida a la que el autor desea servir con un poema acorde a la regla de su orden, obedece al interés suscitado por este tipo de obras entre el público femenino, al que el autor también quiere llegar. Conscientes del poder de atracción de las imágenes, los impresores de los pliegos de la PT optan por acompañar el poema con ilustraciones. Para adornar la portada eligen como reclamo una estampa significativa de la vida de Cristo, la Última Cena o la Crucifixión, el momento previo y final de la Pasión narrada en el interior del cuadernillo a través de las pequeñas viñetas sagradas que los impresores tuvieron a su alcance o copiaron. Salvo el temprano pliego salmantino (c. 1496), los pliegos renacentistas de la $P T$ parecen imitar el modelo iconográfico del Cancionero de Zaragoza (1492), su profusa ilustración, y hasta el más humilde, el sevillano de 1559, no renuncia a ella. El reciente hallazgo de este pliego suelto, tan alejado de la delicada impresión del poema sampedrino en el cancionero zaragozano (92VC), muestra claramente la comentada diversificación editorial de un mismo producto y el interés por la obra después de más de medio siglo de vida. Su descubrimiento confirma igualmente la sospecha de la existencia de otros pliegos perdidos de la $P T$. Es probable que alguno de ellos saliera de la imprenta hispalense de los Cromberger (o de Juan Varela de Salamanca) y que fuera el modelo seguido por Germão Galharde para su impresión portuguesa (c. 1530) y por Juan Gómez para su edición de 1559. Próxima a estas dos ediciones está también la del pliego registrado en

\footnotetext{
${ }^{64}$ En 1872 se recoge en el Romancero y Cancionero Sagrado de Justo de Sancha, Madrid, BAE, t. XXXV, 1872, n. ${ }^{\circ} 909$.
} 


\section{M. ${ }^{a}$ Carmen Marín PinA}

el catálogo de la biblioteca de José Miró y hoy en paradero desconocido ${ }^{65}$, con la diferencia de incluir las «Coplas a una devota monja» que ninguno de los dos citados muestran. Los testimonios conservados son una muestra fehaciente del éxito alcanzado por la Pasión trobada en su primer siglo de vida gracias a la imprenta y al saber hacer de impresores y libreros, que fueron transformando la obra en diferentes productos editoriales, pero también del mismo Diego de San Pedro, que supo acortar y reescribir la versión extensa del poema para darla a las prensas.

Recibido: 29/02/2020

Aceptado: 15/04/2020

${ }^{65} \mathrm{El}$ pliego aparece descrito con suma precisión en el Catalogue de la Bibliothèque Espagnole de don José Miró, París, Librairie Bachelin-Deflorenne, 1878, p. 59, n. ${ }^{\circ} 222$. Al no incluir dichas coplas, no puede identificarse, por tanto, con el pliego suelto de la Hispanic Society ([Lisboa, c. 1530]) como sugieren Askins e Infantes en Antonio Rodríguez Moñino, Nuevo Diccionario bibliográfico de pliegos sueltos poéticos (siglo XVI), edición corregida y actualizada por Arthur L.-F. Askins y Víctor Infantes, Madrid, Castalia, 1997, p. 468, n. $^{\circ} 530$. 


\section{(2)}

La Pasión trobada Por Diego de San Pedro en la imprenta medieval Y RENACENTISTA: DIFUSIÓN DEL POEMA EN CANCIONEROS Y PLIEGOS SUELTOS

Resumen: La Pasión trobada de Diego de San Pedro es un extenso poema sobre la Pasión de Cristo del que se conocen diferentes testimonios manuscritos e impresos. A la imprenta llega una versión abreviada del poema que se difunde a través del Cancionero de Zaragoza impreso por Pablo Hurus (1491, 1492 y 1495) y, de forma exenta, en pliegos sueltos poéticos. En el trabajo se analiza su transmisión impresa, especialmente su difusión en pliegos sueltos, y se atiende a las transformaciones más significativas experimentadas por la obra en su materialidad y contenido en el periodo medieval y renacentista.

Palabras Clave: Cancionero. Pliego suelto poético. Dedicatoria. Grabados. Imprenta.

Pasión trobada by Diego de San Pedro in the medieval and Renaissance PRINTING: DISSEMINATION OF THE POEM IN SONGBOOKS AND VERSE CHAP-BOOKS

Abstract: Pasion trobada by Diego de San Pedro is an extended poem about the Passion of Christ, of which various handwritten and printed testimonials exist. A shortened version of this poem is disseminated in Cancionero de Zaragoza, printed by Pablo Hurus (1491, 1492 y 1495), and also as a standalone in verse chap-books. In this study its printed transmission is analysed, specially its dissemination through verse chap-books, and its most significant transformations experienced by the piece in its materiality and content in the medieval and renaissance times.

KeYwords: Songbook. Verse chap-books. Dedication. Engravings. Printing. 